\title{
Anti NMDA-receptor encephalitis: a severe case (34 year-old male) with psychotic disorders
}

\author{
Cleo Roşculeț ${ }^{1}$, Andrei Rogoz ${ }^{\text {* }}$, Ana Maria Petrescu', Cătălin Apostolescu', Marius Radu', Raluca Zlotea ${ }^{1}$, \\ Doina lovănescu', Cristina Panea ${ }^{2}$ \\ From The 10th Edition of the Scientific Days of the National Institute for Infectious Diseases "Prof Dr Matei \\ Bals" \\ Bucharest, Romania. 15-17 October 2014
}

\section{Background}

Acute encephalitis associated with antibodies to the $\mathrm{N}$-methyl-D-aspartate subtype of glutamate receptor is a recently described condition, the majority of cases presenting as a paraneoplastic syndrome in young females.

\section{Case report}

We report the case of a 34 years-old male with antiNMDA receptor encephalitis who exhibited the classical pattern. The patient described psychiatric symptoms, seizures, movement disorders, altered state of consciousness and autonomic dysfunction, over the course of 40-50 days. After a 20-day hospitalization in a psychiatric ward, the case was redirected to our infectious disease intensive care facility, where he required advanced life support. The interdisciplinary team of infectious diseases, intensive care and neurology specialists raised the diagnosis suspicion of encephalitis. The patient received empirical corticotherapy and therapeutic plasma exchange, with significant clinical improvement in the second week of treatment, coinciding with the diagnostic confirmation by positive results for anti-NMDA receptor antibodies in both serum and cerebrospinal fluid.

The patient continued his recovery in a specialized neurology department. Infectious disease specialists are often confronted with encephalitis of unknown etiology.

\section{Conclusion}

Collaboration with neurologists and psychiatrists with knowledge of this disorder is very important for an early

\footnotetext{
* Correspondence: oopsminded@yahoo.com

${ }^{1}$ National Institute for Infectious Diseases "Prof. Dr. Matei Balş", Bucharest, Romania

Full list of author information is available at the end of the article
}

diagnosis and treatment, as full recovery is a possible outcome for these patients with the correct case management.

\section{Consent}

Written informed consent was obtained from the patient for publication of this Case report and any accompanying images. A copy of the written consent is available for review by the Editor of this journal.

\section{Authors' details \\ 'National Institute for Infectious Diseases "Prof. Dr. Matei Balş", Bucharest, Romania. ${ }^{2}$ Elias University Emergency Hospital, Bucharest, Romania.}

Published: 15 October 2014

doi:10.1186/1471-2334-14-S7-P89

Cite this article as: Roşculet et al: Anti NMDA-receptor encephalitis: a severe case (34 year-old male) with psychotic disorders. BMC Infectious Diseases 2014 14(Suppl 7):P89.

Submit your next manuscript to BioMed Central and take full advantage of:

- Convenient online submission

- Thorough peer review

- No space constraints or color figure charges

- Immediate publication on acceptance

- Inclusion in PubMed, CAS, Scopus and Google Scholar

- Research which is freely available for redistribution

Submit your manuscript at www.biomedcentral.com/submit
() Biomed Central 